DOI: $10.26565 / 2227-8877-2020-91-10$

УДК 811.111:811.161.2]'25

\author{
СТРАТЕГІЇ І МЕТОДИ АНГЛО-УКРАЇНСЬКОГО ПЕРЕКЛАДУ \\ ЗАСОБІВ МОВНОГО ВТІЛЕННЯ ЕТАЛОНІВ ХУДОЖНІХ ПОРІВНЯНЬ \\ Ахмедова Е. Д. \\ аспірант кафедри перекладознавства імені Миколи Лукаша Харківського національного \\ університету імені В. Н. Каразіна; \\ e-mail: elvira.akhmedova.96@gmail.com; ORCID: https://orcid.org/0000-0002-4515-4359; GOOGLE \\ SCHOLAR: https://scholar.google.com/citations?user=oEz_91MAAAAJ\&hl=ru; \\ RESEARCH GATE: https://www.researchgate.net/profile/Elvira_Akhmedova
}

(Харків)

Статтю присвячено аналізу стратегій та методів англо-українського перекладу засобів мовного втілення еталонів художніх порівнянь. Актуальність дослідження зумовлено відсутністю робіт, де б англо-українські переклади художніх порівнянь вивчалися із врахуванням когнітивних моделей, які визначають форму і зміст їхнього мовного втілення. Метою статті є встановлення співвідношення між методами / стратегіями та способами / трансформаціями при перекладі англомовних позначень еталонів художніх порівнянь на українську мову за допомогою когнітивного та структурно-семантичного перекладознавчого аналізу. 3'ясовано, що для англо-українського перекладу засобів мовного втілення еталонів художніх порівнянь використовуються наслідувальний, адаптивний та комунікативний перекладацькі методи. Наслідувальний метод застосовується у рамках перекладацької стратегії очуження і передбачає відтворення когнітивної моделі порівняння, навіть якщо вона не $є$ укоріненою в культурі перекладу. Наслідувальний метод виявляється як формальне наслідування (застосування структурної трансформації транскодування, що спричинює необхідність створення перекладацького коментаря, або експлікації) і змістове наслідування (вживання словникових відповідників). Адаптивний метод корелює з перекладацькою стратегією одомашнення і передбачає заміну або збереження когнітивної моделі порівняння, усунення порівняння або введення нового порівняння у текст перекладу. Адаптивний метод виявляється як формальне адаптування (вживання структурно-функціональних елементів, які не мають аналогів у мові оригіналу), змістове адаптування (застосування змістових трансформацій контекстуальної заміни або цілісного перетворення) і стилістичне адаптування (заміна нейтральних мовних засобів стилістично забарвленими). Комунікативний метод не передбачає вибір між стратегіями одомашнення або очуження, оскільки застосовується у випадку спільних для культур оригіналу і перекладу когнітивних моделей порівняння.

Ключові слова: еталон порівняння, когнітивна модель, метод перекладу, стратегія перекладу.

Ахмедова Э. Д. Стратегии и методы англо-украинского перевода языкового воплощения эталонов художественных сравнений. Статья посвящена анализу стратегий и методов англо-украинского перевода обозначений эталонов художественных сравнений. Актуальность исследования обусловлена отсутствием работ, где бы англо- 
украинские переводы художественных сравнений изучались с учетом когнитивных моделей, которые определяют форму и содержание их языкового воплощения. Целью статьи является установление соотношения между методами / стратегиями и способами / трансформациями при переводе англоязычных обозначений эталонов художественных сравнений на украинский язык с помощью когнитивного и структурно-семантического переводческого анализа. Выяснено, что для англо-украинского перевода обозначений эталонов сравнений используются подражательный, адаптивный и коммуникативный переводческие методы. Подражательный метод применяется в рамках переводческой стратегии форенизации и предусматривает воссоздание когнитивной модели сравнения, даже если она не укоренена в культуре перевода. Подражательный метод реализуется как формальное подражание (использование структурной трансформации транскодирования, что вызывает необходимость создания переводческого комментария, или экспликации) и содержательное подражание (использование словарных соответствий). Адаптивный метод коррелирует с переводческой стратегией доместикации и предусматривает замену или сохранение когнитивной модели сравнения, устранение сравнения или введение нового сравнения в текст перевода. Адаптивный метод проявляется как формальная адаптация (использование структурно-функциональных элементов, которые не имеют аналогов в языке оригинала), содержательная адаптация (применение содержательных трансформаций контекстуальной замены или целостного преобразования) и стилистическая адаптация (замена нейтральных языковых средств стилистически окрашенными). Коммуникативный метод не предполагает выбора между стратегиями доместикации или форенизации, поскольку применяется в случае общих для культур оригинала и перевода когнитивных моделей сравнения.

Ключевые слова: когнитивная модель, метод перевода, стратегия перевода, эталон сравнения.

\section{Akhmedova E. Strategies and methods of English-Ukrainian translation of verbal instantiation of fiction simile}

etalons. This article analyses strategies and methods of English-Ukrainian translation of the names of fiction simile etalons. The topicality of the research results from the fact that English-Ukrainian translations of fiction simile etalons have not been investigated with the account of the simile cognitive models that determine the form and content of their verbal instantiation. The aim of the article is to find correlation between methods / strategies and techniques / transformations in rendering English instantiations of fiction simile etalons into Ukrainian, applying cognitive and structural-semantic translation analyses. The research has discovered three methods used to translate English names of the simile etalons into Ukrainian: faithful, adaptive and communicative. The faithful method correlates with the foreignization translation strategy and presupposes reconstructing the original cognitive models, even if they are not rooted in the culture of translation. The faithful method is applied in its formal (use of structural transformations of transliteration or transcription, which demands introduction of translation commentaries, or explication) and semantic (use of vocabulary equivalents) varieties. The adaptive method correlates with the domestication translation strategy and involves replacing or reconstructing the original simile cognitive model, eliminating the simile or introducing a new simile into the text of translation. The adaptive method manifests itself as formal adaptation (use of structural-functional elements that have no analogues in the original), semantic adaptation (use of semantic transformations of contextual substitution or holistic transformation) and stylistic adaptation (substitution of linguistic units of neutral register with stylistically marked ones). The communicative method does not presuppose making choice between domestication and foreignization, since it is used to translate similes resting on cognitive models that are common for the cultures of the original and translation.

Key words: cognitive model, simile etalons, translation method, translation strategy.

\section{1. ВСТУП}


Встановлення стратегій англо-українського перекладу засобів вербалізації художніх порівнянь $є$ актуальною проблемою перекладознавства, оскільки такий переклад передбачає подолання перекладацьких труднощів, які виникають через особливості культури і мови оригіналу, відображені в еталонах порівнянь.

Англо-українські переклади художніх порівнянь вже були об’єктом перекладознавчих розвідок. На окрему увагу заслуговує дослідження Р. П. Зорівчак, яка встановлює три способи відтворення англійських компаративних фразеологічних одиниць українською мовою: віднайдення повних та часткових еквівалентів, фразеологічне калькування та фразеологічна перефраза [3]. Аналізу англо-українського перекладу компаративних фразеологічних одиниць присвячені роботи й інших авторів [6, 8, 10, 12].

Автори цитованих досліджень зосереджуються на порівняннях, втілених фразеологічними одиницями, зафіксованими у словниках. Поза межами таких досліджень залишаються оригінальні порівняння, які створюються автором художнього твору, що частково зумовлює новизну нашої роботи, у фокусі якої опиняються саме оригінальні авторські порівняння, які є переважно неочікуваними і неповторними (хоча і серед них можуть траплятися фразеологізми). Іншим новим аспектом $\epsilon$ когнітивний ракурс дослідження: наразі англо-український переклад художніх порівнянь ще не вивчався з урахуванням когнітивних моделей порівнянь, які визначають форму їхнього мовного втілення.

Мета нашого дослідження полягає у встановленні кореляцій між методами/стратегіями і способами/трансформаціями англо-українського перекладу засобів мовного втілення еталонів художніх порівнянь.

Завдання дослідження включають: 1) опис інструментів когнітивного аналізу англоукраїнського перекладу художніх порівнянь; 2) виявлення та зіставлення еталонів у структурі когнітивних моделей англійських порівнянь та їхніх перекладів; 3) з'ясування методів та способів/ трансформацій перекладу; 4) встановлення кореляцій між методами/стратегіями і способами/ трансформаціями.

Об'єктом дослідження є український переклад засобів мовного втілення еталонів англійських художніх порівнянь, а предметом - когнітивні і комунікативні аспекти цього перекладу. 
Матеріалом дослідження є 300 художніх англомовних порівнянь, вилучених із роману Донни Тартт «Таємна історія» [23], та їхній переклад на українську мову, виконаний Борисом Стасюком [11].

\section{2. ТЕОРЕТИКО-МЕТОДОЛОГІЧНІ ОСНОВИ ДОСЛІДЖЕННЯ}

У теоретико-методологічному плані робота спирається на діяльнісну концепцію перекладу, де переклад розглядається як «продуктивна, (само)рефлективна творча діяльність перекладача» [9, с. 82], що висуває у фокус уваги когнітивний (когнітивні моделі) та комунікативний (стратегії перекладу, які спираються на ці когнітивні моделі) аспекти українського перекладу засобів мовного втілення еталонів англійських художніх порівнянь.

У когнітивному ракурсі порівняння розглядається як експліцитна концептуальна метафора. За словами Дж. Лакоффа та М. Джонсона, метафора - це «розуміння одного концептуального домену у термінах іншого концептуальної домену» $[19$, с. 4]. Це розуміння грунтується на когнітивній операції концептуального картування, де цільова концептуальна структура (цільовий домен/концепт) пояснюється в термінах вихідної концептуальної структури (вихідного домену/ концепту) [16, с. 210; 17, с. 6; 18]. Метафора грунтується на когнітивній моделі «А є Б», тоді як порівняння спирається на когнітивну модель «А є як Б», де «А» i «Б» $є$, відповідно, цільовими та вихідними концептами/доменами. У структурі порівняння еталон відповідає концепту «Б».

Еталон розуміють як одиницю виміру властивостей та якостей предметів [1; 5; 7]. За ступенем конвенціональності еталони порівняння поділяємо на чотири групи: загальнолюдські, лінгвокультурні, лінгвосубкультурні (соціально-групові) та індивідуальні, наголошуючи на тому, що лінгвокультурні еталони спричинюють найбільші труднощі при перекладі [2, с. 7].

Методи дослідження включають когнітивний перекладацький аналіз: виявлення та співставлення когнітивних моделей порівнянь в оригіналі та перекладі (за методикою [16]) - для встановлення стратегій і методів перекладу і структурно-семантичний перекладацький аналіз - для виявлення способів/трансформацій перекладу засобів мовного втілення еталонів художніх порівнянь.

\section{3. РЕЗУЛЬТАТИ ДОСЛІДЖЕННЯ}


Визначаючи перекладацький метод, дослідники не можуть досягнути єдності у трактуванні цього поняття. У найбільш загальному смислі російські (О. Д. Швейцер [14], В. М. Комісаров [4]), українські (О. В. Ребрій [9], О. І. Чередниченко [13]) та західні (П. Ньюмарк [22]) перекладачі-теоретики розглядають перекладацький метод як сукупність дій (застосування перекладацьких прийомів та трансформацій), які дозволять перекладачу досягти мети і передати зміст тексту оригіналу найбільш «природним» способом.

Найбільш розгорнутою є концепція П. Ньюмарка, який виділяє п’ять основних перекладацьких методів (ми не беремо до уваги дослівний та буквальний методи перекладу, які він вважає підготовчими, до-перекладацькими [22, с. 45-46], та вільний переклад, який він називає «взагалі не перекладом», оскільки він створюється за допомогою перефразування [там само, c. 46-47]):

1) наслідувальний переклад «намагається відтворити точне контекстуальне значення оригіналу в рамках обмежень, що накладаються граматичними структурами ЦМ (тут і далі цільової мови). Він переносить культурні слова мови оригіналу і зберігає ступінь аномальності (відхилення від норм ДМ (джерельної мови)) у перекладі. Він намагається повністю відповідати намірам автора тексту ДМ і їх реалізації» [там само, с. 46];

2) семантичний переклад «враховує естетичну цінність тексту ДМ», але «допускає невеликі зміни, які б полегшили сприйняття тексту читацькою аудиторією мови перекладу» [там само];

3) адаптування «перетворює культуру ДМ в культуру ЦМ» [так само]; до такого перекладу вдаються переважно для передачі п’єс та поезії;

4) ідіоматичний переклад «відтворює смисл оригінального тексту, проте спотворює нюанси значення через надання переваги розмовним висловам та ідіомам у перекладі, хоча вони відсутні в оригіналі» [там само, с. 47];

5) комунікативний переклад «передає чітке контекстуальне значення оригінального тексту у такий спосіб, щоб і зміст і мовні вислови легко сприймалися і були зрозумілими читацькій аудиторії» [там само].

Проаналізувавши матеріал дослідження, ми дійшли висновку, що для перекладу англійських художніх порівнянь на українську мову застосовано три перекладацьких методи: наслідувальний, адаптивний та комунікативний. Комунікативний та наслідувальний перекладацькі методи 
розглядаємо у поданому вище тлумаченні П. Ньюмарка. Щодо адаптивного методу, у нашій інтерпретації він поєднує якості семантичного методу та адаптування. Ідіоматичний переклад тлумачимо як один із варіантів адаптивного методу.

Адаптивний та наслідувальний перекладацькі методи співвідносяться, відповідно, зі стратегіями одомашнення та очуження. На думку Л. Венуті, «одомашнення передбачає дотримання вітчизняних літературних канонів» [24, с. 241], а очуження - «збереження мовних та культурних відмінностей шляхом відхилення від переважаючих вітчизняних цінностей» [так само, c. 240$]$.

Л. Венуті говорить про одомашнення або очуження в тих випадках, коли у перекладача виникають труднощі, які можуть бути спричинені культурними, політичними/ідеологічними чи навіть економічними чинниками [там само]. Відповідно, у контексті когнітивного аспекту перекладу англійських художніх порівнянь на українську мову доречно говорити про стратегії одомашнення або очуження у тих випадках, коли концепти-еталони в когнітивних моделях порівняння в культурі оригіналу і культурі перекладу не збігаються.

У противному випадку перекладачеві не треба обирати між одомашненням та очуженням i він звертається до комунікативного перекладацького методу. Наприклад:

And I was happy in those first days as really I'd never been before, roaming like a sleepwalker, stunned and drunk with beauty [23, с. 9] - Тоді я почувався найщасливішим, блукав, ніби сновида, приголомшений та сп'янілий від краси [11, с. 15].

Оскільки еталон порівняння ЛЮДИНА, ЯКА БЛУКАС У СНI є частиною загальнолюдського знання, у перекладача не виникає труднощів, які б заставляли його обирати стратегію очуження або одомашнення, щоб їх подолати. Відтак перекладач обирає один із словникових відповідників англійського слова (сомнамбула, лунатик, сновида), який найкращим чином вписується у загальний контекст перекладу. Комунікативний перекладацький метод, як правило, зберігає когнітивну модель порівняння.

Наслідувальний перекладацький метод зберігає когнітивну модель порівняння тексту оригіналу, навіть якщо концепт-еталон художнього порівняння $є$ невкоріненим в українській культурі. Розмежовуємо: 1) формальне і 2) змістове наслідування. 
Формальне наслідування має місце у випадках, коли перекладач застосовує суто структурні трансформації, як скажімо, транскрибування власних назв, які механістично переносять концепт-еталон в текст перекладу:

Before I know it, you'll have hair down to your shoulders and be skulking around in rags like Howard Hughes [23, с. 127]. - Я не встигну й моргнути, а в тебе патли відростуть по плечі, $i$ тинятимешся тут у лахмітті, наче Говард Г’юз [11, с. 229].

Перекладач використовує адаптивну транслітерацію для передачі власної назви Howard Hughes на позначення особи, яка у тексті оригіналу слугує еталоном міського божевільного, хоч $\mathrm{i}$ може передбачити, що українські читачі, скоріше всього, не матимуть уявлення про цю особу. У таких випадках перекладачі, зазвичай, компенсують втрату змісту коментарем, в якому вони надають інформацію, важливу для розуміння перекладу: «Говард Робард Г’юз-мол. (1905-1976) американський підприємець, кінопромисловець, авіаційний новатор і філантроп. Славився ексцентричною вдачею, страждав на серйозну форму обсесивно-компульсивного розладу» [12, c. 229]. Іншим способом надати читачеві додаткову інформацію $\epsilon$ лексико-граматична трансформація експлікації:

They tended to sound like Heckle and Jeckle [23, с. 153]. - У подібному настрої-збентежені, розчаровані - вони завжди звучали, немов дві мультяшні сороки - Гекл і Джекл [11, с. 274].

У цьому прикладі автор тексту оригіналу порівнює близнюків, Чарлі та Каміллу, з двома ідентичними сороками 3 американського мультфільму. Перекладач застосовує адаптивну транслітерацію для передачі імен Heckle and Jeckle, на позначення персонажів, які є еталоном ідентичності/схожості. Оскільки перекладач усвідомлює, що ці імена можуть нічого не говорити українському читачеві, він вважає за потрібне пояснити, що це персонажі американського мультфільму, для чого додає прикметник мультящні.

Змістове наслідування є перекладом за допомогою змістових трансформацій, як наприклад, калькування зі знаходженням прямих словникових відповідників кожного із компонентів відповідного словосполучення:

Patrick offered her an arm and she slipped a gloved hand in the crook of his elbow, inscrutable behind her dark glasses, calm as a bride [23, c. 237]. - Патрік подав їй руку, вона взяла його попід неї долонею в рукавичиі, загадкова за темними окулярами, спокійна, немов наречена [11, с. 421]. 
Перекладач дослівно передає українською оригінальне речення, де наречена постає як еталон спокою і врівноваженості. Вислів calm as a bride не $\epsilon$ фразеологізмом. Це індивідуальноавторське порівняння створила уява авторки. Перекладач передає його буквально, переносячи цей неочікуваний концепт-еталон в текст перекладу, хоча важко уявити собі людину, яка б хвилювалася менше нареченої у такий пам’ятний день.

Адаптивний перекладацький метод реалізується як: 1) змістове адаптування, 2) формальне адаптування і 3) стилістичне адаптування або ідіоматизація.

Змістове адаптування відбувається на рівні когнітивних моделей і включає: а) заміну концепту-еталона в когнітивній моделі порівняння; б) усунення порівняння; в) додавання порівняння у перекладі.

Проілюструємо висловлені положення, починаючи із заміни концепту-еталона порівняння:

They'd been drunk the night before, they told me, drunk as bandicoots [23, c. 105] - Казали, щуо минулого вечора налигалися як свині [11, с. 189].

Слово bandicoot означає великого щура, який руйнує сільськогосподарські культури [21]. Строго кажучи, еталон, позначений словом bandicoot, є субкультурним, тобто бандикут є добре знайомим представникам будь-якої лінгвокультури, які захоплюються грою в комп'ютерні ігри, оскільки це персонаж серії комп’ютерних ігор під назвою "Crash Bandicoot", випущеної у 1996 році компанією "Sony Computer Entertainment". Наразі в інтернеті можна знайти серії смішних малюнків iз зображенням п’яного бандикута [20]. Проте, зваживши на те, що цей персонаж є не настільки відомим масовій українській читацькій аудиторії, щоб він міг виконати функцію еталона сп’янілої людини, перекладач вдається до заміни еталону на його український аналог - свиню, використовуючи лексичну трансформацію контекстуальної заміни.

\section{Усунення порівняння:}

Hарру as a clam [23, с. 223] - Радощуів повні штани [11, с. 396].

Happy as a clam $€$ фразеологічним зворотом зі значенням «такий, що почувається або виглядає радісним чи задоволеним» [15, с. 649]. Позначення еталона clam перекладається на українську мову як молюск, проте для української аудиторії молюск не асоціюється з радістю. Для пересічного носія англійської мови і культури етимологія фразеологізму втрачена, і він, скоріш за 
все, сприймається цілісно, носії мови не концентруються на значенні слова clam. Відтак, цілком прийнятним видається застосуванням перекладачем лексичної трансформації цілісного перетворення, що хоча і приводить до втрати порівняння, проте цілком відображає смисл зображеної в оригіналі ситуації, але вже засобами української лінгвокультури.

\section{Введення порівняння:}

And the stiff way he walks, sort of a limp [23, с. 33]. - А ходить, як кривенька качечка, тому що досі накульгує [11, с. 57].

Хоча оригінал лише містить інформацію про те, що референт накульгує, перекладач вдається до порівняння референта 3 кривенькою качечкою за допомогою лексичної трансформації смислового розвитку.

Окрім змістового адаптування, втіленого введенням у текст перекладу порівняння, відсутнього в оригіналі, перекладач вдається і до формального адаптування, яке реалізується через використання у перекладі структурно-функціональних елементів української мови, яких немає в мові оригіналу, насамперед, емотивно-забарвлених зменшувальних і збільшувальних суфіксів. Ці елементи не змінюють когнітивної моделі порівняння, і стосуються лише форми іiі мовного втілення. У аналізованому випадку формальне адаптування досягається шляхом використання зменшувальних суфіксів іменника на позначення еталона порівняння (-еч-) і його означення-прикметника (-еньк-).

Більш того, у аналізованому перекладі прослідковується і стилістичне адаптування, яке, як і формальне, не змінює когнітивної моделі порівняння, проте передбачає зміну стилістичного регістру: вирази, що вживаються на позначення еталонів порівняння в тексті оригіналу і тексті перекладу, належать до різних стилістичних регістрів. У той час як в оригіналі використано нейтральні у стилістичному відношенні мовні засоби, у перекладі знаходимо ім'я персонажа 3 української народної казки - кривеньку качечку, неміч якої викликала співчуття у діда з бабою, i вони полюбили іï як рідну доньку. Порівняння з кривенькою качечкою вжито для характеристики одного з головних героїв твору, Генрі, який, хоч і накульгував, проте був природженим лідером, виключно сильною, жорсткою і, як виявилося, небезпечною людиною. Він міг викликати страх або захоплення, проте ніяк не співчуття. Відтак, введення у текст перекладу цього порівняння навантажує його культурною інформацією, яка не сприяє передачі смислу оригінального тексту. 


\section{4. ВИСНОВКИ ТА ПЕРСПЕКТИВИ ПОДАЛЬШИХ ДОСЛІДЖЕНЬ}

Результати когнітивного і структурно-семантичного перекладацького аналізу надають нам змогу встановити кореляції між методами/стратегіями і способами/трансформаціями англоукраїнського перекладу засобів мовного втілення еталонів художніх порівнянь.

Для українського перекладу засобів мовного втілення англійських еталонів художніх порівнянь застосовується три перекладацьких методи: наслідувальний, адаптивний та комунікативний.

Комунікативний метод $\epsilon$ нейтральним щодо стратегій очуження та одомашнення. Він задіюється у випадках, коли художні порівняння у тексті оригіналу і перекладу грунтуються на

спільних когнітивних моделях, і реалізується переважно за допомогою прямих словникових відповідників.

Наслідувальний метод корелює 3 перекладацькою стратегією очуження і передбачає збереження когнітивної моделі художнього порівняння шляхом транскодування мовних засобів на позначення еталона, який є незнайомим українській аудиторії, що спричинює створення перекладацького коментаря чи застосування трансформації експлікації безпосередньо у тексті перекладу (формальне наслідування), або шляхом вживання словникових відповідників (змістове наслідування).

Адаптивний метод породжується перекладацькою стратегією одомашнення, де перекладач вдається до заміни когнітивної моделі, усунення або, навпаки, введення порівняння у текст перекладу шляхом застосування контекстуальної заміни або цілісного перетворення (змістове адаптування), збереження когнітивної моделі, проте, разом з тим, вживання структурнофункціональних елементів, які не мають аналогів у мові оригіналу (формальне адаптування) або заміни нейтральних мовних засобів стилістично забарвленими (стилістичне адаптування).

Перспективи дослідження пов’язуємо зі встановленням кількісних кореляцій між методами/стратегіями і способами/трансформаціями англо-українського перекладу засобів мовного втілення еталонів художніх порівнянь.

\section{ЛІТЕРАТУРА}


1. Академічний тлумачний словник української мови: [в 11 т.]. Київ : Наукова думка, 1970-1980.

2. Ахмедова Е. Д. Стратегії англо-українських перекладів мовного втілення еталонів порівнянь у художньому тексті. Science And Education A New Dimension. Philology. 2019. Вип. VII (61). С. 7 9.

3. Зорівчак Р. П. Фразеологічна одиниця як перекладознавча категорія (на матеріалі перекладів творів української літератури англійською мовою) : монографія. Львів : Вид-во при Львів. унTi, 1983. $175 \mathrm{c}$.

4. Комиссаров В. Н. Современное переводоведение : учеб. пособие. Москва : ЭТС, 2002. 424 с.

5. Красных В. В. «Свій» среди «чужих»: миф или реальность? Москва : ИТДГК «Гнозис», 2003. $375 \mathrm{c}$.

6. Кушина Н. І. Відтворення етномовного компонента українських народних казок в англомовних перекладах : автореф. дис. на здобуття наук. ступеня кандидата філол. наук : 10.02.16. Київ, 1998. $17 \mathrm{c}$.

7. Маслова В. А. Лингвокультурология : учеб. пособие для студ. высш. учеб. заведений. Москва : Издательский центр «Академия», 2001. 203 с.

8. Молчко О. О. Художнє порівняння як категорія перекладознавства (на матеріалі української та англійської мов) : дис. на здобуття наукового ступеня канд. філол. наук : 10.02.16. Львів, 2015. $256 \mathrm{c}$.

9. Ребрій О. В. Сучасні концепції творчості у перекладі : монографія. Харків : ХНУ імені В. Н. Каразіна, 2012. 376 c.

10. Тарасова А. В. Відтворення англійських компаративних фразеологізмів інтенсифікаторів в українських перекладах : автореф. дис. на здобуття наук. ступеня кандидата філол. наук : 10.02.16. Дніпропетровськ, 2017. 20 с.

11. Тартт Д. Таємна історія. Харків : Книжковий клуб «Клуб Сімейного Дозвілля», 2017. 560 с.

12. Цепенюк Т. О. Відтворення авторських перетворень компаративних фразеологічних одиниць інтенсифікуючого значення українською мовою. Studia Methodologica. 2011. № 32. С. 67-71.

13. Чередниченко О. І. Про мову і переклад. Київ : Либідь, 2007. 248 с.

14. Швейцер А. Д. Теория перевода : Статус, проблемы, аспекты. Москва : Наука, 1988. 215 с.

15. Concise Oxford English Dictionary : Book \& CD. Oxford : Oxford University Press, 2011. 1682 c. 
16. Kovalenko L., Martynyuk A. English container metaphors of emotions in Ukrainian translations. Advanced Education. № 10, 2018. P. 190-197.

17. Kövecses, Z. Levels of metaphor. In Cognitive linguistics, 28 (2), 2017. P. 321-347.

18. Kövecses, Z. Metaphor : A practical introduction. Oxford : Oxford University Press, 2002. 285 p.

19. Lakoff, G. The contemporary theory of metaphor. Metaphor and thought. Cambridge : Cambridge University Press, 1993. P. 202-251.

20. LET'S GET CRASHED! Drunk Crash Bandicoot. URL: https://www.google.com/search? $\mathrm{q}=$ Crash + Bandicoot + drunk\&tbm=isch\&ved=2ahUKwi21eTXhZjoAhU-yMQBHc2CC3wQ2 $\quad$ дата звернення: 14.03.2020).

21. Merriam-Webster : Definition of bandicoot. URL: https://www.merriam-webster.com/dictionary/ bandicoots (дата звернення: 27.02.2020).

22. Newmark, P. A. Textbook of Translation. Shanghai : Shanghai Foreign Language Education Press, 1988. $292 \mathrm{p}$.

23. Tartt, D. The Secret history. New York: Vintage, 2015. 319 p.

24. Venuti, L. Strategies of Translation. Routledge Encyclopedia of Translation Studies. London \& New York : Routledge, 2001. P. 240-244.

\section{REFERENCES}

Akademichnyi tlumachnyi slovnyk ukrainskoi movy: [v 11 t.] [Academic dictionary of Ukrainian : [in 11 volumes]]. (1970-1980). Kyiv : Naukova dumka.

Akhmedova, E. D. (2019). Stratehii anhlo-ukrainskykh perekladiv movnoho vtilennia etaloniv porivnian u khudozhnomu teksti [Strategies of English-Ukrainian translations of verbal instantiation of simile etalons in fiction]. Science And Education A New Dimension. Philology, 88, 7-9 (in Ukrainian).

Zorivchak, R. P. (1983). Frazeolohichna odynytsia yak perekladoznavcha katehoriia (na materiali perekladiv tvoriv ukrainskoi literatury anhliiskoiu movoiu) [Phraseological unit as a translation category (on the material of translations of Ukrainian literature into English)]. Lviv: Publishing House of Lviv Polytechnic National University.

Komissarov, V. N. (2002). Sovremennoye perevodovedeniye : ucheb. posobiye [Modern translation studies : manual for graduate students]. Moscow : ETS Publ. 
Krasnykh, V. V. (2003). "Svoy" sredi "chuzhikh" : mif ili realnost? [Welcomed among strangers : myth or reality?]. Moscow : ITDGK Gnosis Publ.

Kushyna, N. I. (1998). Vidtvorennia etnomovnoho komponenta ukrainskykh narodnykh kazok v anhlomovnykh perekladakh. Avtoref. diss. dokt. filol. nauk [Reproduction of ethnographic component of Ukrainian folk tales in English translations. Dr. philol. sci. diss. Synopsis]. Kyiv (in Ukrainian).

Maslova, V. A. (2001). Lingvokulturologiya : ucheb. posobiye dlya stud. vyssh. ucheb. zavedeniy [Linguoculturology : manual for graduate students]. Moscow : Akademiya Publ.

Molchko, O. O. (2015). Khudozhnie porivniannia yak katehoriia perekladoznavstva (na materiali ukrainskoi ta anhliiskoi mov). Diss. dokt. filol. nauk [Artistic simile as a category of translation studies (in Ukrainian and English)]. Lviv. 256 p. (in Ukrainian).

Rebrii, O. V. (2012). Suchasni kontseptsii tvorchosti u perekladi. Monohrafiia [Modern conceptions of creativity in translation. Monograph] Kharkiv. 376 p. (in Ukrainian).

Tarasova, A. V. (2017). Vidtvorennia anhliiskykh komparatyvnykh frazeolohizmiv intensyfikatoriv v ukrainskykh perekladakh. Avtoref. diss. dokt. filol. nauk [Reproduction of English comparative phraseologisms of intensifiers in Ukrainian translations. Dr. philol. sci. diss. Synopsis]. Dnipropetrovsk (in Ukrainian).

Tartt, D. (2017). Taiemna istoriia [The secret history]. Kharkiv: Knyzhkovyi klub "Klub Simeinoho Dozvillia".

Tsepeniuk, T. O. (2011). Vidtvorennia avtorskykh peretvoren komparatyvnykh frazeolohichnykh odynyts intensyfikuiuchoho znachennia ukrainskoiu movoiu [Reproduction of the author's transformations of comparative phraseological units of intensifying meaning in Ukrainian]. Ternopil. nats. pedahohichnyi un-t im. V. Hnatiuka. - Ternopil Volodymyr Hnatyuk National Pedagogical University, 246, 67-71 (in Ukrainian).

Cherednychenko, O. I. (2007). Pro movu i pereklad [About language and translation]. Kyiv : Lybid Publ.

Shveytser, A. D. (1988). Teoriya perevoda : Status, problemy, aspekty [Translation Theory: Status, Problems, Aspects]. Moskva : Nauka Publ.

Concise Oxford English Dictionary : Book \& CD. (2011). Oxford : Oxford University Press. 
Kovalenko, L., and Martynyuk, A. (2018). English container metaphors of emotions in Ukrainian translations. Advanced Education, 205, 190-197 (in English).

Kövecses, Z. (2017). Levels of metaphor. Cognitive linguistics, 28 (2), 321-347.

Kövecses, Z. (2002). Metaphor : A practical introduction. Oxford : Oxford University Press.

Lakoff, G. (1993). The contemporary theory of metaphor. In Metaphor and thought. Cambridge : Cambridge University Press, 678, 202-251.

LET'S GET CRASHED! Drunk Crash Bandicoot. Available at : https://www.google.com/search? $\mathrm{q}=$ Crash + Bandicoot + drunk $\&$ tbm=isch\&ved=2ahUKwi21eTXhZjoAhU-yMQBHc2CC3wQ2.

Merriam-Webster. (2020). Definition of bandicoot. Available at : https://www.merriamwebster.com/dictionary/bandicoots.

Newmark, P. A. (1988). Textbook of Translation. Shanghai : Shanghai Foreign Language Education Press.

Tartt, D. (2015). The Secret history. New York : Vintage.

Venuti, L. (2001). Strategies of Translation. Routledge Encyclopedia of Translation Studies. London \& New York : Routledge, 654, 240-244.

\section{CВЕДЕНИЯ ОБ АВТОРЕ / INFORMATION ABOUT THE AUTHOR}

Ахмедова Эльвира Джавадовна - аспирант кафедры переводоведения имени Николая Лукаша Харьковского национального университета имени В. Н. Каразина; e-mail: elvira.akhmedova.96@gmail.com; ORCID: https://orcid.org/0000-0002-4515-4359; GOOGLE SCHOLAR: https://scholar.google.com/citations?user=oEz_91MAAAAJ\&hl=ru; RESEARCH GATE: https://www.researchgate.net/profile/Elvira_Akhmedova

Akhmedova Elvira - Ph.D. candidate at Mykola Lukash Translation Studies Department of V. N. Karazin Kharkiv National University; e-mail: elvira.akhmedova.96@gmail.com; ORCID: https:// orcid.org/0000-0002-4515-4359; GOOGLE SCHOLAR: https://scholar.google.com/citations? user $=$ oEz_91MAAAAJ\&hl=ru; RESEARCH GATE: https://www.researchgate.net/profile/ Elvira_Akhmedova 